\section{A HISTORICAL PERSPECTIVE OF 有 YǑU IN THE CHINESE LANGUAGE $^{1}$}

\section{Chanyaporn Chawla ${ }^{2}$}

\section{บทคัดย่อ}

ในวงการภาษาศาสตร์ภาษาจีนได้ให้ความสนใจศึกษา

การใช้คำ 有 $y o ̌ u$ มาเป็นเวลานานแล้ว แต่การศึกษา เหล่านี้ยังจำกัดอยู่เพียงหน้าที่ของคำ有 $y \check{u}$ เฉพาะยุค สมัยหนึ่ง ๆ (เช่น ในสมัยโบราณหรือสมัยปัจจุบัน เป็นต้น) ทั้งยังขาดคำอธิบายว่าเพราะเหตุใดในบางยุค

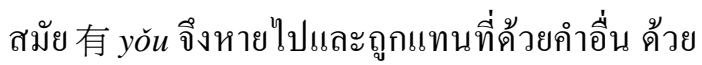
เหตุนี้ บทความนี้จะสังเคราะห์และแสดงให้เห็นความ ความหลากหลาย ในหน้าที่ ของคำ 有 $y \check{u}$ ใน ประวัติศาสตร์การพัฒนาตั้งแต่ยุคโบราณจนกระทั่งถึง ยุคปัจ จุบัน รวมทั้งให้คำอธิบายถึงลักษณะทาง อรรถศาสตร์และวากยสัมพันธ์ของคำดังกล่าว นอกจากนี้บทความนี้ยังสนับสนุนความคิดเห็นของ ชอปเปอร์และทรอกอธ (2003) ว่าคำเนื้อหา (content word)

1 (มุมมองของประวัติศาสตร์คำ 有 $\boldsymbol{y}$ ǒu ในภาษาจีน) This work was supported by the Research Group on Cognitive -Typological Linguistics, Center of Excellence Program on Languages, Linguistics and Literature, Faculty of Arts, Chulalongkorn University, Bangkok. Also, I wish to express my gratitude to Acharn William Whorton for valuable comments.

2 (ชัญญพร จาวะลา) Assistant professor, Department of Eastern Languages, Faculty of Arts, Chulalongkorn University, Bangkok
(ราชบัณฑิตยสถาน, 2010: 98) สามารถเปลี่ยนเป็นคำบ่ง หน้าที่ทางไวยากรณ์ (grammatical word) ผ่าน กระบวนการกลายเป็นคำไวยากรณ์ได้

\begin{abstract}
In Chinese linguistics, there has been a long-term interest in the many uses of 有you. However, a number of these studies limit the functions of 有 you only to a particular period (i.e. the Archaic or Modern period). Moreover, explanations as to why 有 you lost its dominance and was substituted by other words is rarely given. Thus, this paper will synthesize the key interpretations on the variety of functions of 有 you during their development from the Archaic to Modern Chinese periods, and provide explanations for its semantic and syntactic characteristics. In addition, this paper also supports Hopper and Traugott (2003)'s view that during the process of grammaticalization, a content word can shift its function to be $a$ grammatical one.
\end{abstract}

\section{Introduction}

In recent years, research on 有 yǒu has provoked much interest among linguists in the field of Chinese syntax. This research has mainly investigated the functions of 有 yǒu in either the Archaic or Modern period. For example, the discussion of the function of 有 yǒu in '有+NP' patterns in Archaic times (Li, Y., 1982; Huang,Y., 1985; Zhang, 1996; Cai, 1997; Guo. L., 2012), the functions of 有 yǒu in specific classical 
literature, such as Lunyu ${ }^{3}$ or Guoyu $u^{4}$ (Song, 1996; Ni, 2004), the perfective aspect marker 有 yǒ in the Archaic period (Liu, 1996) and the functions of 有 yǒu as a preposition (Xu, 2000), a verb (Wang, T., 2004), and in '有 +VP' construction in Modern Chinese grammar (Yang and Dong, 2005; Cui, 2013). However, only a few scholars have discussed the development and grammaticalization process of 有 yǒu (Wang and Zhou, 2012; Sui, 2013). Though these scholars have provided certain functions of 有 yǒ $u$ across time, they have not given an explanation as to why 有 you and its counterparts having similar functions, such as the demonstrative 兹 $z \bar{l}$, the conjunction 又 yòu and 零 ling, coexisted and finally why one lost its dominance and was replaced. Secondly, the path of change of the widely used perfective aspect form, '有 $+\mathrm{V}$ ' in the old time into ' $\mathrm{V}+了$ ' in Modern Chinese has not been taken into consideration. Consequently, this paper will be based on data drawn from relevant studies on this topic and the Center for

3 Lunyu (论语 also known as The Confucian Analects) is a collection of sayings and ideas by the philosopher Confucius and conversations with his disciples in the Warring States period (战国 Zhànguó, 476-221 B.C.) (Theobald, 2010 In Lunyu. Retrieved December 11, 2014, from http://www.chinaknowledge.de/Literature/ Classics/lunyu.html).

${ }^{4}$ Guoyu (国语 also known as Discourses of the States) is a collection of historical records between rulers and ministers in the Spring and Autumn period (春秋 Chūnqiū, 771 - 476 B.C.) (Theobald, 2010 In Gиоуи. Retrieved December 11, 2014, from

http://www.chinaknowledge.de/

Literature/Historiography/guoyu.html).
Chinese Linguistics (CCL) Corpus developed by Peking University ${ }^{5}$ to describe the linguistic development of 有 yǒu from the Archaic to Modern Chinese periods. Particular attention is paid to the development of 有 yǒ u from a verb into a demonstrative word, an adverb, a conjunction, a perfective aspect marker and a comparative marker.

This paper is structured as follows: the first section is an introduction to this study. The second section presents a review of the relevant literature. The third section explains the diachronic development of 有 you found from the Archaic to the Modern periods. The last section summarizes and offers some speculation as to the significance of the findings.

\section{Background of the Study: Review of Related Literature}

To better our understanding of the historical development of 有 yǒu, I first provide a summary of previous studies.

$\mathrm{Li}$ and Thompson (1981) point out that there are quite a few languages in the world, including Mandarin Chinese that use the same verb to express "possession" and "existence". Teng's (1973) and that observation on the negatives and aspects of Chinese can support this claim. In Teng's article, he explains that in the French, Spanish and Japanese languages, the existential verb 有 yǒu asserts the existence

\footnotetext{
${ }^{5}$ However, several frequently used examples in the Modern Chinese period have been created by the author.
} 
of an event or state. Moreover, $\mathrm{Li}$ and Thompson also explain the reason why in many languages the same verb instead of two or more different verbs is used to express "possession" and "existence". The reason is that the relationship between possessor and possessee is more or less the same as the relationship between the existence of a thing and its space ( $\mathrm{Li}$ and Thompson, 1981, 1989).

Besides the study of 有 yǒ on its meanings, some scholars such as Zhang (1996) and Yang and Dong (2005) have investigated elements that follow 有 yǒu. Zhang's study on '有 (无) $+\mathrm{NP}^{\prime}{ }^{6}$ claiming that '有 (无) $+\mathrm{NP}$ ' construction was first introduced in the Pre-Qin era. NP itself can express either action or property and the NP that follows 有/无 you/wú can be replaced by the pronoun 之 $z h \bar{\imath}$. Furthermore, Yang and Dong report that, in Modern Chinese grammar, it is ungrammatical if 有 yǒu is followed by a verb phrase ${ }^{7}$. However, this pattern is commonly used among the young generation in Taiwan to emphasize an action and property that has happened or is happening. For example, 我有看过这部电 影。Wŏ yŏu kànguo zhèbù diànyĭng. "We have seen this movie", or 从那个时候, 我 每天都有去学校。Cóng nàgè shíhou, wŏ méitiān dōu yŏu qù xuéxiào. "Since then I went to school every day".

\footnotetext{
6 'NP' stands for 'Noun phrase'

${ }^{7}$ Verb phrase (hereafter, 'VP')
}

\section{The Diachronic Development of 有 Yǒu 有 Yǒu as a Verb}

Shuo Wen Jie $\mathrm{Zi}^{8}$ explains 有 yǒu as a phonetic compound that is constructed from the radical 月 yuè "meat" and the pronunciation of 又 yò "hand". However, Wen (1993) argues that this explanation is incorrect. He proposes that 有 yǒ u should consist of the pictograph 又 at the top, and the radical 月 yиè (肉 ròu “meat") at the bottom, meaning, "to carry some meat in the hand."

Additionally, according to Jin's (2012) investigation, the word 有 yǒu consists, etymologically, of the sign for the right hand (又). However, he claims that 有 yóu on the tortoise shells of the Shang Dynasty $\left(16^{\text {th }}-11^{\text {th }} c\right.$. B.C.) has quite a few different meanings such as “to have", 又 yò " "to add", 佑 yò "blessing", 侑 yò "to urge someone to eat". Jin explains that 有 yǒu has a lot of meanings because of its phonetic constitution. At the beginning stage, the morpheme is polysemous. Then, each meaning develops its own character. However, the new forming character still preserves the radical "hand".

Other information on 有 yǒu is given by Yang and He (1992), and Guo, Q (2003).

\footnotetext{
${ }^{8}$ Shuo Wen Jie Zì (说文解字 also known as Explaining and Analyzing Compound Characters) is the oldest and one of the most important Chinese character compositions compiled by Xu Shen. (Theobald, 2010 In Shuo Wen Jie Zì. Retrieved December 11, 2014, from http://www.chinaknowledge.de/Literature/Scienc e/shuo wenjiezi. html).
} 
Yang and $\mathrm{He}$ point out that 或 huò is substituted by 有 yǒu in some contexts. Guo, Q (2003) uses tortoise bone number sixteen as evidence to prove that the character 又 yò first existed on the tortoise bone, but later people borrowed 有 yǒ $u$ to substitute 又 yòu. Also, the word meaning "to urge someone to eat" separated itself from 有 you and formed the new character, 侑 yòu. This example can be found in Jiaguwen or the oracle bone and Shijing ${ }^{9}$ as shown below (Guo, Q., 2003).

$$
\begin{aligned}
& \text { 召唤子渔给祖乙举行侑祭。《甲 } \\
& \text { 骨之二十・叶王事》 } \\
& \text { Zhàohuàn Zǔyú gěi Zŭyŭ jŭxíng yòu } \\
& \text { jì. (Jiăgǔwén èrshí: Yèwáng shì) } \\
& \text { Zhaohuan Ziyu-give-Zuyi (King } \\
& \text { Shang's ancestor)-organize-to urge } \\
& \text { someone to eat- } \\
& \text { to offer a sacrifice } \\
& \text { Zhaohuan Ziyu organized the } \\
& \text { sacrifice ceremony for Zuyi (King } \\
& \text { Shang's ancestor). }
\end{aligned}
$$

\footnotetext{
${ }^{9}$ Shijing (诗经 also known as Book of Songs) is also one of the five Classics of ancient Chinese literature. It collects 305 works of the Chinese poetry in the Zhou period (周 Zhōu, 1050221B.C.) (Theobald, 2010 In Shijing. Retrieved December 11, 2014, from http://www.chinaknowledge.de/Literature/Classi cs/shijing.html).
}

use-sacrifice, use-seat-use-to urge to eat, use-assist-bright-happiness We proceed to make spirits and prepare viands, for offerings and sacrifice;

We seat the representatives of the dead, and urge them to eat. Thus seeking to increase our bright happiness. (translated by Legge, 1898)

At that time, 有 followed by NPs was quite common. Wen (1993) points out that from “carrying some meat in one's hand", 有 yǒu gives the concept of "possession." Later, the meaning of "there is" is derived from this concept.

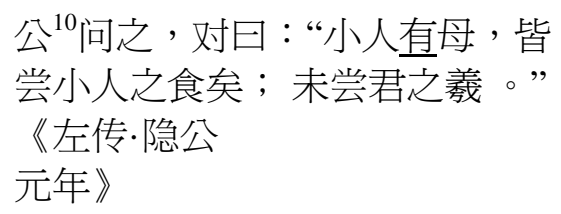

Gōng wèn zhī, duì yuē: "Xiăo rén yŏ mŭ, jiē cháng xiăorén zhī shí y̌̆; wèi cháng jūn zhī yì." (Zuŏzhuàn: Y̌̌ngōng yuán nián) Zhuanggong-ask-him, reply-say: Ihave-mom, all-taste-I-POSS ${ }^{11}$-foodPAR $^{12}$; not-taste-king-POSS-ready cooked meat

Zhuanggong asked him and he replied: "I have a mom. She tasted all of my food but she has never tasted the king's ready cooked meat."

\footnotetext{
${ }^{10}$ 公 Gōng here refers to 莊公 Zhuānggōng "Zhuanggong"

11 'POSS' stands for 'Possessive adjective'

12 'PAR' stands for 'Particle'
} 
野有死麇、白茅包之。《诗经: 召 南（野有死麇）》

Yě yŏu š̌ jūn, bái máo bāo zhī. (Shījing: Zhàonán (Yě yŏu sǐ lù)) Wild-there is-dead-antelope, whitegrass-wrapped up-it In the wild there is a dead antelope, and it is wrapped up in the white grass (translated by Legge, 1898)

鼓钟伐嘉, 淮有三洲。《诗经·北山 之什 (鼓钟)》

Gŭ zhōng fá gāo, Huái yŏu sān zhōu. (Shījing: Běishān zhì shí (Gŭ zhōng)) Drum-bell-knock-beat, Huai-there is-three-Islands

His bells ring out, his large drums resound, there are the three islands in the Huai. (translated by Legge, 1898)

先生不羞, 乃有意欲为收责于薛 乎? 《战国策·冯谖客孟尝君》

Xiānsheng bù xiū, năi yŏuyì yù wèi shōu zhài yú Xuē hu? (Zhànguócè: Féngxuān kè Mèng Chángjūn) Mister-not-humiliate, but-willingwant-for (someone)-collect-debtPREP $^{13}$-Xue-PAR?

Mister, I do not wish to embarrass you but can you help in collecting the debt in Xue?

Above, objects that follow 有 yŏ can be a simple noun as in (3). In (4) 死 $s \check{\imath}$ "die" is an adjective used to modify 麇 jūn "antelope" which is a noun. In (5), the object of 有 yŏ

13 'PREP' stands for 'Preposition' numeral adjective 三 sān "three". Based on Sui (2013)'s view, '有 $+\mathrm{NUM}+\mathrm{N}$ ' ${ }^{14}$ is a pattern developed from '有+NP'. In (6), 有 you is followed by the abstract noun, 意 $y \grave{\imath}$ “intention" forming '有 +NP' which is an idiomatic word.

Apart from the aforementioned '有 + NP' patterns, we can find pivotal construction, an extended form deriving from the verb 有 yŏ meaning "existence". According to $\mathrm{Li}$ and Thompson (1989), pivotal construction is a construction that has a NP which is the subject of the second verb and at the same time is the direct object of the first verb. Such an NP functions as a "pivot" relating the two verbs. In the following examples, the pivotal NP is shown in italics.

$\mathrm{NP}_{1} \quad \mathrm{~V}_{1}$ (有)

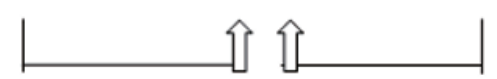

有乌高飞、亦傅于天。《诗经·非 风(苑柳) 》

Yŏu niăo gāo fēi, yì fù yú tiān.

(Shījinng: Bèifēng (Wănliǔ))

There is-bird-high-fly, also-close-

PREP-heaven

There is a bird flying high, even up to heaven. (translated by Legge, 1898)

（8）有朋自远方来、不亦乐乎。《论 语·为政第一》

14 'NUM' stands for 'Number' 
Yơu péng zì yuăn fāng lái, bù yì lè hū.(Lúnyŭ: Wéi zhèng dì ȳ̄)

Have-friend-from-distant-quarterscome, not-also-delightful-PAR?

Is it not delightful to have friends coming from distant quarters?

(translated by Legge, 1893)

According to Yang and $\mathrm{He}$ (1992), $\mathrm{V}_{1}$ (有) expresses the existence of an object, whereas the following verb or $\mathrm{V}_{2}$ describes the action or the state attributable to the pivot. They divide the pivotal construction into two different groups according to the function contained in the pivot itself.

Yang and He (1992) claim that the subject of the $\mathrm{NP}_{1}$ can be omitted because the sentence mainly discusses an existence. In 有朋远方来 Yŏu péng zì yuăn fāng lái "have friends coming from distant quarters", $\mathrm{NP}_{1}$ is dropped. Thus the form of this pivotal construction is as follows:

$\left(\mathrm{NP}_{1}\right)$

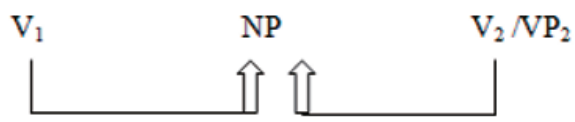

$\begin{array}{lll}\text { (吾) } & \text { 有 } & \text { 朋 } \\ \text { (Wú) } & \text { yŏu } & \text { péng } \\ \text { ( I ) } & \text { have } & \text { friend }\end{array}$

自远方来

zì yuăn fāng lái

coming from distant quarters

"Is it not delightful to have friends coming from distant quarters?

\section{有 Y̌̌u as a Demonstrative}

The 'Demonstrative ${ }^{15}$ ' is mainly used when emphasizing a noun that follows (Guo, L., 2012). In Shangshu and Shijing, 有 yŏu is frequently found with a 'proper noun ${ }^{16}$, forming

‘有+PropN' pattern, as shown in example (9).

我不可不监于有夏, 亦不可不监
于有殷。《命书·召诰》
Wŏ bù kě bù jiāan yú yŏu Xià, yì bù
ké bù jiān yú yŏu Yìn. (Shàngshū:
Zhàogào)
I-not-possible-not-warn-PREP-
DMT-Xia, and-not-possible-not-
warn-PREP-DMT-Yin
I might take warning from Xia, and
also take warning from Yin.

Researchers unanimously agree that those 'PropN' include kingdom, location, surname and tribes' names. However, they disagree on the part of speech of 有 you. Four major views exist on the function of 有 you in this pattern. The first view, maintained by Wang, Y (1978) and Xia (1989), claims that 有 yŏu is an auxiliary word. The exclusion of 有 you from '有 + PropN' pattern makes the 'PropN' unable to stand alone as a word. The second view, proposed by scholars such as Yang, B (1981), Wen (1993) and Ni (2004), states that 有 you is a prefix which does not contain any meaning. Yang, B (1981) further observes that the '有 + PropN' pattern is particularly used for the beat rhythm in poetry, as commonly found in Shijing. Ni (2004) supports Yang's study by

\footnotetext{
${ }^{15}$ Demonstrative word (hereafter, 'DMT')

${ }^{16}$ Proper noun (hereafter, 'PropN')
} 
pointing out that 有 yŏu has the same function as the prefix 阿 $\bar{a}$ in Modern Chinese. The third view, introduced by Huang, Q (1981) claims that 有 yŏu, in this pattern, functions as a demonstrative pronoun. Huang, Y. (1985) agrees with Huang, Q (1981)'s argument that each tribe has its own distinctive characteristics and culture that makes it different from others. Huang, Q (1981), using the data from Shangshu ${ }^{17}$, Zuozhuan ${ }^{18}$ and Shijing, provides an elaborate explanation to support his claim. As he explains, the word 邵 Shào means “a plow”. So, 有邵 yŏu Shào shows that this kind of farming tool is unique to the Zhou tribe. One more example is the word 殷 Yīn which means “clothing”. So, 有殷 yŏ $Y \bar{i} n$ implies that the Yin people were the first tribe to learn how to produce clothing to cover their bodies. The fourth view suggested by Qin and Zhang (1985), claims that 有 you connects to 国 guó "kingdom" in the Archaic period. Therefore, 有夏 yŏu Xià has the same meaning as 夏国 Xià guó 'Xia kingdom,' or 有周 yŏu Zhōu has the same meaning as 周国 Zhōu guó 'Zhou kingdom'.

17 Shangshu (向书 also known as Book of Documents) is a collection of sayings of rulers and governers from the ancient time to the middle of the Western Zhou period (西周 $X \bar{l}$ Zhōu, 1046-771 B.C.) (Theobald, 2010 In Shangshu. Retrieved December 11, 2014, from http://www.chinaknowledge.de/Literature/Classi cs/shangshu. html)

${ }^{18}$ Zuozhuan (左传 also known as Commentary of $\mathrm{Zuo}$ ) is a narrative text which is a parallel version to the chronicle Spring and Autumn Annals. (Theobald, 2010 In Zuozhuan. Retrieved December 11, 2014, from

http://www.chinaknowledge.de/Literature/Classi cs/chunqiuzuozhuan.html).
Many scholars such as Li, Y (1982), Huang, Y (1985) and Guo, L (2012) accept the third view. However, Li,Y (1982) and Guo, L (2012), deny that 有 yŏu is an auxiliary word because without 有 you the element that follows can still stand alone and function as a word. Moreover, based on Guo, L's investigation, words that follow 有 yŏu are not rhythmical. So, he rejects that 有 you is a prefix used in poetry.

The '有+PropN' pattern was actively used during the Xia to the Western Zhou dynasty (西周 Xìzhōu 1050-771 B.C.). However, it is rarely found after The Spring and Autumn period (Guo, L., 2012) or the Han dynasty (汉 Hàn 206 B.C. - 220 A.D.) (Ni, 2004). According to Guo, L (2012), the '有 +PropN' pattern coexisted with '兹+PropN' pattern in the Archaic period. He cites several examples from Shangshu and Zuozhuan. For example, 有殷 yŏu Yīn and 有宋 yŏu Sòng can be substituted by 兹殷 $z \bar{l}$ Yìn, and 兹宋 $z \bar{\imath}$ Sòng respectively, as shown in examples (10) and (11).

The '有+PropN' pattern was actively used during the Xia to the Western Zhou dynasty (西周 Xīzhōu 1050-771 B.C.). However, it is rarely found after The Spring and Autumn period (Guo, L., 2012) or the Han dynasty (汉 Hàn 206 B.C. - 220 A.D.) (Ni, 2004). According to Guo, L (2012), the '有 + PropN' pattern coexisted with '兹+PropN' pattern in the Archaic period. He cites several examples from Shangshu and Zuozhuan. For example, 有殷 yŏu Yīn and 有宋 yŏu Sòng can be substituted by 兹殷 $z \bar{l}$ $Y \bar{i} n$, and 兹宋 $z \bar{\imath}$ Sòng respectively, as shown in examples (10) and (11). 


\section{有 $Y \grave{o} u^{19}$ as a Conjunction}

Hornby (1994: 246) defines a 'conjunction' as a grammar word that joins words, phrases or sentences, i.e. and, but, or. Guo, X (2005) observes that dating back to the Shang period (c.1600 - c.1046 B.C.), conjunctions like 有 yòu, 又 yòu, 及 jí, 则 zé, 若 ruò are used. In the case of 有 yòu, it is used to connect an integer or a counting number and its remainder, meaning 'and'. Moreover, it is probable that the conjunction 有 yòu is derived from the verb 有 yŏu (Guo, X., 2005). He provides some examples of 有 $y \grave{o} u$ as a conjunction that are shown in (12) and (13).

$$
\begin{aligned}
& \text { 豕七十有六, 獐一百有九十有九。 } \\
& \text { 《乙, 764》 } \\
& \text {..., shĭ qīshí yòu liù, zhāng yībăi yǒu } \\
& \text { jiǔshí yǒu jiǔ (Yi, 764) } \\
& \text {.., pig-seventy-and-six, river deer- } \\
& \text { one hundred-CONJ }{ }^{20} \text {-ninety-and- } \\
& \text { nine } \\
& \text {.., there are seventy-six pigs, and } \\
& \text { one hundred and ninety-nine river } \\
& \text { deers }
\end{aligned}
$$

(13) 肇十有二州, ... 《佮书·尧典》

Zhào shí yòu èr zhōu,... (Shàngshū: Yáo diăn)

To establish-ten-and-two-state

To establish twelve states,...

Guo, X (2005) observes that in the

Warring States period $^{21}$, 有 yòu as a

19 有 $y \check{o u}$ as a conjunction is pronounced yòu (He, Ao, Wang, Mai \& Wang, 1985). This is because 又 yòu “to add" and 有 yòu were interchangeable in the Archaic time.

${ }^{20}$ CONJ stands for 'Conjunction' conjunction gradually disappeared, as is shown in examples (14) and (15).

待我二十五年不来而后嫁。《左 传·僖公二十三年》

Dài wǒ èrshí wǔ nián bù lái ér hòu jià (Zuŏzhuàn: Xīgōng èrshísān nián) Wait-me-twenty-five-year-notcome-then-remarry Wait for me twenty-five years and if I do not come back, then you may remarry.

人之身三百六十节。《韩非子.解 老》

Rén zhī shēn sānbăi liùshí jié.

(Hánfēizĩ: Jiě lăo)

Human-POSS-body-three-hundredsixty-joint

The human body has three hundred and sixty joints.

Later, at the end of the Archaic period, the conjunction 有 yò $u$ was used in the counting of numbers which have zero (Long, 2008), as shown in example (16).

东西五亿有九万七千里。《吕氏 春秋》

Dōngxī wǔ yì yòu jiǔ wàn qũ qiān lǐ. (Lüshì Chūnqiū)

East-West-five-hundred millionCONJ-ninety seventhousand-li ${ }^{22}$

\footnotetext{
${ }^{21}$ Some writers deliberately bring back the old style and use this pattern. Thus, this form kept on appearing until the first half of the 20th century (Guo, X., 2005).

22 里 $l i$ is a measure word. $1 \mathrm{li}$ is equal to 500 meters (Measurement Law, 1929 Retrieved December 19, 2014, from
} 
The distance from East to West is 500,097,000 li.

In (16), there are zeros between five hundred million and ninety-seven thousand.

\section{有 $Y \check{o} u$ as an Adverb}

Wen (1993) gives an explanation as to why 有 you is used as an adverb by referring to Wang Yinzhi's work. Wen explains that 有 yŏ can be used to express the characteristics and intensity of words. Moreover, based on He et al. (1985) and Ni (2004)'s observation, 有 you as an adverb is widely used in Shijing, ${ }^{23}$ as is shown in examples (17) and (18).

(17) 隰桑有阿、其叶有难。《诗经. 小 雅 (隰桑) 》

Xí sāng yŏu ā, qí yè you nán.(Shījing: Xiăoyă (Xí sāng))

http://zh.wikipedia.org/wiki/\%E5\%B8\%82\%E5\%88\% B6).

23 Additional examples of adverb 有 yŏ 天, 有蕡其实。《诗经.桃天》Táo zhī yāo yāo, yǒu fèi qí shí .(Shïjing: Táo yāo) "The peach tree is young and elegant; Abundant will be its fruits." (translated by Legge, 1898) or 不以我归, 忧心有 忡。《诗经·击鼓》Bú y̌̌ wǒ guī, yōu xīn yǒu chōng. (Shī jīng: Jī gǔ) "[But] he did not lead us back, and our sorrowful hearts are very sad." (translated by Legge, 1898) (He et al., 1985). However, in the latter period, 有 you as an adverb is rarely found. Only an example from Shiji (史记 also known as The Record of the Grand Historian) (Chinese Text Project, n.d. Retrieved December 20, 2014, from http://ctext.org/shiji/zhs) has been found. For example, 居官有忧。居家多灾。

《史记·龟策列传第六十八》Jūguān yǒu yōu. Jüjiā duō zāii. (Shĭjì: Guīcè lièzhuàn dì liùshí bā) 'Being an official will bring concerns. Living with family will cause a lot of trouble."
Wet-mulberry-there is-beautiful, itleaf-ADV ${ }^{24}$-luxuriant In the low, wet grounds, the mulberry trees are beautiful! And their leaves are luxuriant. (translated by Legge, 1898)

$$
\begin{aligned}
& \text { 子兴视夜, 明星有烂。《诗经·郑 } \\
& \text { 风 (女白鸡鸣)》 } \\
& \text { Zì xīng shì yè, míng xīng yŏu làn. } \\
& \text { (Shījing: Zhèngfēng (Nü bái jī } \\
& \text { míng)) } \\
& \text { You-get up-look-night, the morning } \\
& \text { star-ADV-bright } \\
& \text { You should get up and look at the } \\
& \text { night, the morning star is shining } \\
& \text { brightly. }
\end{aligned}
$$

In (17), 有 you emphasizes that the mulberry leaves are luxuriant, while in (18) it stresses that the morning star is bright.

\section{有 Yŏu as a Perfective Aspect Marker ${ }^{25}$}

Liu (1996) observes that in the Archaic Chinese period, '既 $+V$ ' was used to indicate the completion of an action, as shown in example (19). However, in the same period, we can also find '有 $+\mathrm{V}$ ' pattern used in the same sense. The difference between both patterns is 有 yŏu emphasizes the finished action or realization more, as shown in example (20).

$$
\begin{aligned}
& \text { 宋人既成列，楚人未既济。《左 } \\
& \text { 传·僖公二十二年》 } \\
& \text { Sòngrén jì chéng liè, Chǔrén wèi jì } \\
& \text { jì. (Zuŏzhuàn: Xīgōng èrshí èr nián) }
\end{aligned}
$$

\footnotetext{
24 'ADV' stands for 'Adverb'

${ }^{25}$ Perfective aspect marker (hereafter, 'PAM')
} 
Song-people-ADV-become-line, Chu-people-not-ADV-cross Song people ${ }^{26}$ lined up but Chu people had not crossed the river.

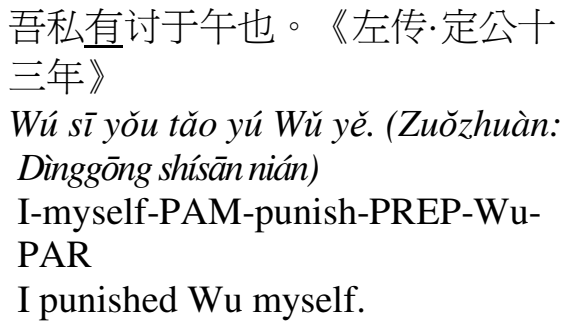

Wú sī yǒu tăo yú Wǔ yě. (Zuŏzhuàn: Dinggōng shísān nián) I-myself-PAM-punish-PREP-WuPAR

I punished Wu myself.

In (19), 既 $j i$ is used in front of two verbs, 成 chéng and 济 jì respectively, to indicate the completed action. The same condition exists when 讨 tăo 'to punish' in (20) appears after 有 yǒu. It indicates that the mentioned action, "punish", was successfully done.

Medieval Chinese ( $3^{\text {rd }}$ c. B.C. - $13^{\text {th }}$ c. A.D.)

\section{有 Y̌̆u as a Verb}

Just as in the Archaic period, the verb 有 yoru in this period mainly expresses the concept of 'possession' and 'existence'.

$$
\begin{aligned}
& \text { 公 }{ }^{27} \text { 有珊瑚笔格, 平生珍惜。《欧 } \\
& \text { 阳修.珊瑚笔格》 } \\
& \text { Gōng yŏu shānhú bìgé, píngshēng } \\
& \text { zhēnxī. (Ōu Yángxiū: Shānhú bŭgé) } \\
& \text { Sigong-has-coral-pen rest, all one's } \\
& \text { life-treasure } \\
& \text { Sigong had a coral pen rest. He } \\
& \text { treasured it all his life. }
\end{aligned}
$$

\footnotetext{
26 人 rén 'people' here indicate 'the army'

27 公 Gōng refers to "Sigong”
}

胎中有红蟹子，小如豆，螯足皆 具。《刘恂·岭表录异》

Tāi zhōng yŏu hóng xièž̆, xiăo rú dòu, áo zú jiē jù. (Liú Xún: Ling biăo lù yì)

Stomach-in-there is-red-crab, smalllike-bean, pincer-leg-all-have There is a small red crab in its stomach, as small as a bean but with all. As pincers and legs.

家有一李树, 结子殊好, ... 《世 说新语·德行第一》

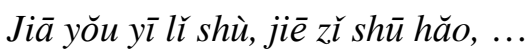

(Shì shuō xīn yǔ: Dé xíng dì yi)

House-there is-one-plum tree, bearfruit-really-good,...

There is a plum tree in the house. It bears really good plums,....

\section{……而文日益有名。《韩愈. 与陈}

给事书》

.... Ér wén rìỳ̀ youumíng. (Hán Yù:

Yŭ Chén jŭ shì shü)

... but-writing-increasingly-famous

.... but I am increasingly famous for my writing.

In (21), the NP is two nouns linked together, and the main noun 笔格 b̆gé "pen rest" is modified by 珊瑚 shānhú "coral"; in (22), 蟹子 $x i e ̀ z \breve{l}$ "crab" is modified by the adjective 红 hóng "red". In (23), the object of 有 you is a NP which is modified by the numeric adjective - $y \bar{\imath}$ "one". In (24), 有 yŏu is followed by a noun, 名 míng "name", forming an idiomatic word. 
In addition, 有 yŏ $u$ as a pivotal construction continued to be used, as shown in examples (25) and (26).

有人持璧遮使者曰：“为吾遗滈池 君。”《史记·秦始皇本纪》

Yǒu rén chí bì zhē shǐzhě yuē: "Wéi wú yí Hàochíjūn." (Shìjì:

Qínshǐhuáng běnji)

There is -person-bring-jasper-stopmessenger-say: "replace-me-offer as a gift-Haochijun"

A person who was carrying jasper stopped the messenger and said: "Help me send it to Haochijun."

\section{有吏夜抓人。《杜甫·石壕村》 \\ Yŏu lì yè zhuā rén. (Dùfu: \\ Shíháocūn)}

There is-official-night-catch-people There is an official coming to catch people at night.

During the Wei and the Song dynasties (220-1279), 有 yŏ appeared in a new pattern showing numerical order (e.g. $1^{\text {st }}$ kind, $2^{\text {nd }}$ kind, etc.). This pattern is an extension of 有 yŏ (Wang \& Zhou, 2012), as in examples (27) and (28).

疑有二种：一烦恼疑 ; 二无记 疑。《六朝·佛经》

Yí yǒu èr zhǒng: yī fánnăo yí; èr wújì yí. (Liùcháo: Fójīng)

Doubt-has-two-kind: one-worrydoubt; two-neutral nature-doubt There are two kinds of doubt: one is doubt because of worry and the other is doubt because of having a neutral nature. ${ }^{28}$

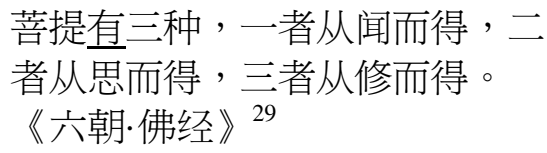

Pútí yǒu sān zhǒng, yīzhě cóng wén ér dé, èrzhě cóng sī ér dé, sān zhě cóng xiū ér dé. (Liùcháo: Fójīng) Buddha-has-three-type, one-fromSavaka-and-become, two-fromPacceka-become, three-frommeditate-and-become Buddhahood has three types; the first one is becoming Savaka Buddha, the second one is becoming Pacceka Buddha; and the third one is becoming Samma Sambuddha (enlightened and becoming a Buddha through the meditation approach).

In (27) and (28), elements that follow 有 yŏu are groups of things that have similar qualities or characteristics.

\section{有 $Y \breve{o u}$ as a Demonstrative}

\footnotetext{
${ }^{28}$ The neutral nature here implies a feeling of uncertainty.

${ }^{29}$ 闻 wén comes from the word 声闻 Shēngwén 'Savaka Buddha', 思 sī indicates 缘觉 yuánjué 'Pacceka Buddha'. For more details, see The Corpus of Pure Land. (n.d). Retrieved December 19, 2014 from http://wap.goodweb.cn/index.asp.
} 
In the former period, 有 you were commonly found in front of the kingdom, location, surname and tribes' names, forming the '有/兹+PropN' pattern. Though some examples have been found in classical records such as Shiji, Jiu Tang Shu, this usage sharply decreased in the Medieval period $(\mathrm{Ni}, 2004)$.

$$
\begin{aligned}
& \text { 闾夭之徒患之, 乃求有莘氏美 } \\
& \text { 女, ..... 《史记·周本纪》 }
\end{aligned}
$$

Hōng Yāo zhī tú huàn zhī, năi qiú yŏu Shēn shì měi nǘ,.... (Shüjì: Zhōu běnjì)

Hong Yao-POSS-feel worry-him ${ }^{31}$, so-find-DMT-Shen-surname-

beautiful-woman,...

Hong Yao feels worried about Xibo because Xibo cannot find a beautiful girl whose surname is Shen.

In this period, the '兹+GenN' pattern which appeared in the former period gained more popularity ${ }^{32}$. Examples of '兹+GenN' can be found in Hou Hanshu ${ }^{33}$, Da Dai $\mathrm{Liji}^{34}$

\footnotetext{
${ }^{30}$ Only one example of the '兹 PropN' pattern in the Pre-Modern period, Qing dynasty is to be found in the CCL Corpus. This example is 今兹 宋人夺我国书《续资治通鉴.二百二十卷》Jīn zī Sòngrén duó wŏ guóshū (Xù Zīzhì tōng jiàn: Èrbǎi èrshí juàn) "Now Song people stole our credentials".

31 The word 'him' here refers to 西伯 Xībó "Xibo"

${ }^{32}$ However, this pattern lost its popularity in the Pre-Modern period. I found only one example, 兹邦 $z \bar{l}$ banng "Xibo" from《殊域周咨录》, a literary work written in the Ming dynasty (明 Míng 1368-1644 A.D.).

${ }^{33}$ Hou Hanshu (后汉书 also known as Book of the Later Han Dynasty) is an official document
}

(Guo, L., 2012) $)^{35}$, also in Weishu ${ }^{36}$ and Songshu ' $^{37}$. Thus, causing '有 + GenN' to lose its dominance.

$$
\begin{aligned}
& \text { 迄兹夏弥口祸... 《旧唐书》 } \\
& \text { Qì zi xià mí } \square^{38} \text { huò. (Jiùtángshū) } \\
& \text { Up until-DMT-summer-full-?- } \\
& \text { misfortune } \\
& \text { Up until summer, life is full of } \\
& \text { misfortune. }
\end{aligned}
$$

\section{有 Yòu as a Conjunction}

Two functions of 有 yò remained in use in this period. We can find the use of these two functions in the linking of the integer and its

depicting the history of the Han dynasty (Theobald, 2010 In Hou Hanshu. Retrieved December 11, 2014, from http://www.chinaknowledge.de/Literature/Histori ography/houhanshu.html).

${ }^{34}$ Da Dai Liji (大戴礼记 also known as Records of Ritual Matters by Dai Senior) is a collection of ritual matters written during the Han dynasty (Theobald, 2010 In Da Dai Liji. Retrieved December 11, 2014, from http://www.chinaknowledge.de/Literature/ Classics/dadailiji.html).

${ }^{35}$ This pattern has not existed for a long time

${ }^{36}$ Weishu (魏书 also known as The Book of the Wei Dynasty) is an official dynastic history of the Wei dynasty (Theobald, 2010 In Weishu Retrieved December 11, 2014, from http://www.chinaknowledge.de/Literature/ Historiography/weishu.html).

${ }^{37}$ Songshu (宋书 also known as The book of the (Liu-)Song) is the historical text of the Song dynasty (Theobald, 2010 In Songshu Retrieved December 11, 2014, from http://www.chinaknowledge.org/Literature/ Historiography/songshu.html)

${ }^{38}$ The square here means this character does not exist in the Modern period. 
remainder and the insertion of a number with nought (number zero), as shown in examples (31) and (32).

尔来二十有一年矣。《三国演义. 第九十一回》

Ér lái èrshí yòu yī nián yǐ. (Sānguó yănyì: Dì jiǔshí yī huí)

Since that time-twenty-CONJ-oneyear-PAR

Since that time it has been twentyone years.

七万有四百四十三级。《史记·卫
将军骠骑列传》
Qìwàn yòu sìbăi sìshí sān jí. (Shǐji:
Wèi jiāngjun biāo qí lièzhuàn)
Seven thousand-CONJ-four
hundred-forty-three-CL ${ }^{39}$ for the
head that is cut off
Seven thousand four hundred and
forty-three (70,443) heads (of the
enemy) were cut off.

In (31) 有 yòu is used to link number 'twenty' with number 'one', while in (32) 有 yò $u$ is inserted between number 'seventy thousand' and 'four hundred'.

In addition, in this period, ' $\mathrm{NUM}_{1}+$ 有 $+\mathrm{NUM}_{2}{ }^{\prime}$, as shown in example (31) continuously coexisted with $\mathrm{NUM}_{1}+\mathrm{NUM}_{2}$ pattern (with the omission of 有 youn), as shown in example (33).

$$
\begin{aligned}
& \text { 定是二百五十沓乌樏。《世说新 } \\
& \text { 语·下卷》 } \\
& \text { Dìng shì èrbăi wŭshí dá wūlěi (Shì } \\
& \text { shuō xīn yǔ: Xià juàn) } \\
& \text { Order-is-two hundred fifty-CL-tray }
\end{aligned}
$$

39 'CL' stands for 'Classifier'
Order two hundred and fifty trays of food

\section{有 Yŏu as a Perfective Aspect Marker ${ }^{40}$}

As in the Archaic period, in Medieval time 既 jì and 有 yŏ $u$ have still used to indicate the completed action, as shown in examples (34) and (35).

\section{夫人既有身亡，家内营其殡送。 《敦煌变文集·欢喜国王缘》}

Fūrén jìyǒu shēnwáng, jiānèi yíng qí bìn song. (Dūnhuáng biànwénjí:

Huānxĭ guó wáng yuán)

(Huanxi king)'s wife-ADV-pass away, family-inside-arrange-herfuneral-send The King of Huangxi's wife passed away, her family arranged her funeral ceremony.

\section{若鬼神有知, 不受邪位之诉。}

《世 说新语.容止第十四》

Ruò gŭ̌ shén yŏu zhī, bù shòu xié nìng zhī sù. (Shì shuō xīn yŭ:

Róngzhì dì shísì)

If-ghost-spirit-PAM-know, not-getwicked person-POSS-tell

If the ghost and spirit knew, they would not listen to the flattering words told by the wicked person.

Examples (34) 既 jì co-occurs with 有 you to indicate that the state of 身亡 shennwáng "pass away" has happened, while in (35) 有 you indicates the state 知 $z h \bar{l}$ "to know" that it had already happened.

\footnotetext{
${ }^{40}$ Perfective aspect marker (hereafter, 'PAM')
} 
However, after the Han dynasty, 有 you as a PAM gradually lost popularity (Liu, 1996).

\section{Pre-Modern Chinese $\left(14^{\text {th }}-18^{\text {th }}\right.$ c. $)$}

\section{有 Y̌̌u as a Verb}

Similar to the Medieval period, 有 yŏu as a verb in Pre-Modern times can be followed by NP to form the '有+NP' pattern, as shown in examples (36-40). However, different from the former era, a '有 +NUM+CL+NP' pattern appeared and became more popular than the former one, '有 $+\mathrm{NUM}+\mathrm{NP}$ '. Moreover, '有+NP' forming idiomatic words, gained more popularity at this stage.

随身俱有钟表，不论大小事，都有 一定的时刻。《红楼梦.第十四 回》

Suíshēn jù yǒu zhōngbiăo, bùlùn dà xiăo shì, dōu yǒu yìdìng de shíkè.(Hónglóumèng: Dì shísì huí) Carry on oneself-has-watches, no matter-large-small-matter, everything-has- $\mathrm{ATT}^{41}$-fixed-time By carrying a watch on oneself, no matter a large or small matter, everything is done in a fixed time.

只听后院中有笑语声, 说: “我来 迟了，没得迎接远客！”。《红楼 梦.第三回》

Zhī tīng hòuyuànzhōng yǒu xiàoyǔ shēng, shuō: "Wó lái chí le, méidé yíngjiē yuăn kè!” (Hónglóumèng: Dì sān huí)

41 'ATT' stands for 'Attributive'
Only-hear-back courtyard-hascheerful talking-sound, say: "Icome-late-PAM, do not-welcomedistant-guest"

Only (Lin Daiyu) heard the cheerful talking sound from the back courtyard. The voice said: "I am too late, and not in time to welcome the distant guest!"

还有一女, 比薛蟠小两岁, 乳名 宝钗, ... 《红楼梦.第四回》

Háiyǒu ȳ̄ nǘ, b̌̌ Xuē Pán xiăo liăng suì, rǔmíng Băochāi,...

(Hónglóumèng: Dì sì huí)

Also-has-one-daughter, compare-

Xue Pan-small-two-year, infantname-Baochai (She) also had a daughter who was two years younger than Xue Pan. This infant girl's name is Baochai.

如今父母俱已亡故, 身边只有两 个老嬤嬤。《红楼梦.第十七回》 Rújīn fùmǔ jù yı̌ wánggù, shēnbiān zhīyǒu liăngge lăo mómo. (Hónglóumèng: Dì shí qĩ huí) Now-father and mother-all-ADVpass away, by one's side-only-hastwo-CL-old-nurse

Now that her father and mother had already passed away, she had only two old nurses by her side.

这个地方儿有趣! 《红楼梦. 第五

回》

Zhège dìfāngr yǒuqù!

(Hónglóumèng: Dì wǔ huí)

This-CL-place-interesting

This place is interesting. 
In (36), 有 yǒu is followed by the NP 钟表 zhōngbiăo "watches". In (37), the 声 shêng “sound" is a modified by 笑语 “cheerful talking". In (38) and (39), the object of 有 you is a NP modified by a numeral adjective. The difference between (38) and (39) is that example (39) has a CL, so forming the '有 $+\mathrm{NUM}+\mathrm{CL}+\mathrm{N}$ ' pattern. In (40) 有 yŏu is followed by the noun, 趣 qù "interest" forming an idiomatic word.

As in former periods, pivotal patterns and those showing numerical orders were commonly found throughout this time, as shown in examples (41) and (42).

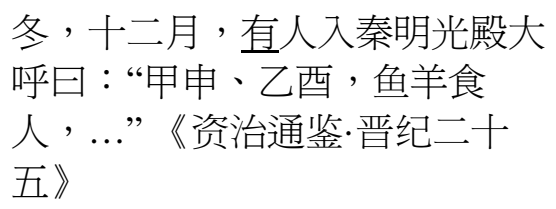

Dōng, shièr yuè, yǒu rén rù Qín Míngguāngdiàn dà hū yuē: "Jiă Shēn, Y̌̌ Yơu, yú yáng shí rén,...”(Zī zhì tōng jiàn: Jinjì èrshí wǔ) Winter, December, there is-personenter-Qin-Mingguang hall-speaking in a loud voice-say: "Jia Shen year, Yi You year, fish-sheep-eatpeople,..." In the winter period of December, one entered Qin Mingguang Hall and spoke in a loud voice: "Either in the Jia Shen year or in the later Yi You year, fish and sheep ${ }^{42}$ would eat people"

${ }^{42}$ Fish and sheep here implies 鲜卑人 Xiānbēi rén 'Xianbei people'. See Gushiwen Wang. 资 治通鉴 [Comprehensive Mirror for the Ruler]. Retrieved December 19, 2014 from
(42)

\author{
果品却只有五样：一是红柊，二是 \\ 栗子，三是落花生，四是菱角，五 \\ 是香芋。《红楼梦.第二十四回》 \\ Guǒpinn què zhǐyǒu wǔ yàng: yī shì \\ hóngzăo, èr shì lìzi, sān shì \\ luòhuāshēng, sì shì \\ língjiăo, wǔ shì xiāngyù. \\ (Hónglóumèng: Dì èrshí sì huí)
}

Fruit-yet-only-have-five-kind: oneis-red date, two-is-chestnut, three-isground nut, four-is-waternut, five-istaro

The fruit, however, has five kinds: first is red date, second is chestnut, third is groundnut, fourth is waternut, and fifth is taro.

In (41), 人 rén functions as the object of 有 yóu and the subject of the following elements. In (42), 有 yǒ u is followed by the names of fruit in a string.

In addition, 有 yǒu in the pattern '有 +NUM+CL+ADJ' appeared in this period, giving the concept of: "thing that reaches the specific amount or degree". 有 yǒu in this pattern is also derived from 有 yǒu which denotes the meaning of 'existence'. Consider examples (43) and (44).

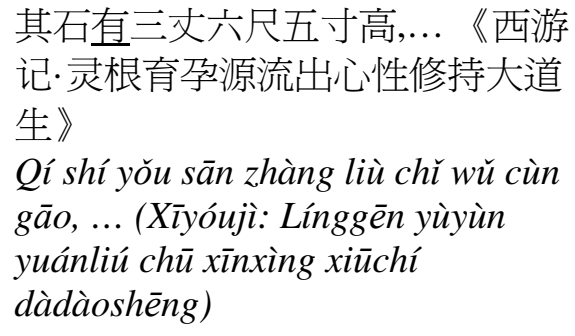
记·灵根育孕源流出心性修持大道 生》

Qí shí yǒu sān zhàng liù chĭ wǔ cùn gāo, ... (Xīyóujì: Línggēn yùyùn yuánliú chū xīnxìng xī̄chí dàdàoshēng)

http://www.gushiwen.org/GuShiWen_287922eed 1.aspx 
That-rock-there is-three-zhang-sixchi-five-cun-high

That rock is 12.66 meters high. ${ }^{43}$

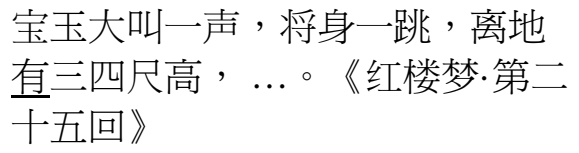

Băoyù dà jiào yī shēng, jiāng shēn ȳ̄ tiào, lí dì yǒu sānsì chĭ gāo,... (Hónglóumèng: Dì èrshí wǔ huí) Baoyu (person name)-scream-voice, with-body-jump, far away fromground-there is-three-four-chi-high Baoyu screamed in a loud voice. He jumped up about one meter high from the ground.

\section{有 Yòu as a Conjunction}

Similar to former periods, 有 yòu has remained in use with number, as shown in examples (45) and (46)

$$
\begin{aligned}
& \text { 卜魁户口二万有二十七, 墨尔根 } \\
& \text { 五千七百三十八, 艾浑一万三千 } \\
& \text { 有二十四。《龙沙纪略》 } \\
& \text { Bōkuí hùkǒu èrwàn yòu èrshí qī, }
\end{aligned}
$$

\footnotetext{
${ }^{43}$ Based on the measurement system, 3 丈 zhàng is equal to 10 meters, 3 尺 $c h \grave{i}$ is equal to 1 meter, and 3 寸 cùn is equal to 10 centimeters (Measurement Law, 1929 Retrieved December 19, 2014, from http://zh.wikipedia.org/wiki/\%E5\%B8\%82\%E5 $\% 88 \%$ B6).
}

hundred-thirty-eight, Aihun-ten thousand-CONJ-twenty-four The total population of Bokui is twenty thousand and twenty-seven people, Mo Er Gen is five thousand seven hundred and thirty-eight, Aihun is thirteen thousand and twenty-four
尔来三十有七载，... 《三月六日 登鼓楼看花》
Ěrlái sānshí yòu qī zăi, ... (Sān yuè liù rì dēng Gǔlóu kàn huā)
Since then-thirty-CONJ-seven-year It is thirty-seven years since then.

However, during the Ming and Qing dynasty, 零 ling “zero" appeared, as in (47).

$$
\begin{aligned}
& \text {..., 发心要写三千六百五十零一部 } \\
& \text { 《金刚经》 } 44 \text { 《红楼梦.第八十 } \\
& \text { 八回》 } \\
& \text {..., fā xīn yào xiě sānqiāan liùbăi } \\
& \text { wǔshí líng yì bù Jīngāngjīng. (Hóng } \\
& \text { Lóumèng: Dì bāshí bā huí) } \\
& \text {.., promise-will-write-three } \\
& \text { thousand-six hundred-fifty-CONJ- } \\
& \text { zero-one-section-Jinggangjing } \\
& \text {..., (The old lady) promises } \\
& \text { (Buddha) that she will write three } \\
& \text { thousand six hundred and fifty-one } \\
& \text { sections of Jinggangjing. }
\end{aligned}
$$

\section{有 Y̌̆u as a Perfective Aspect Marker}

In the Pre-Modern period, 有 you as a perfective aspect marker was still used. However, it should be noted that in this period, two patterns '有+VP' and '有 $+\mathrm{V}$ 过'

\footnotetext{
${ }^{44}$ One of the Buddhist Classic books
} 
were co-used to indicate the completed action, as shown in examples (48) and (49).

他 ${ }^{45}$ 问了我好几遍：可有看见他的

绢子。《红楼梦.第二十六回》

Tā wènle wǒ hăoǰ̀ biàn: kě yǒu kànjiàn tā de juànzǐ. (Hónglóumèng: Dì èrshí liù huí)

She-ask-PAM-me-several-times: whether-PAM-see-her-POSShandkerchief

She has asked me several times whether I had seen her handkerchief.

见了大众, 俱请安问好。内中也 有见过的, 还有一两家不曾见 过。《红楼梦.第七十一回》 Jiànle dàzhòng, jù qǔng'ān wènhăo. Nèizhōng yě yǒu jiànguo de, háiyŏu yìliăng jiā bù céng jiànguo (Hónglóumèng: Dì qīshí yī huí) Meet-PAM-many people, all-to pay respect-to greet. Inside-also-hasmeet-PAR, also-has-one-twofamily-not-before-meet-PAR (They) met many people, greeted and paid their respects to them. Of those guests, they had seen some of them; while there were one or two families they had not seen before.

In (48) and (49), '有+VP' is used to indicate a completed action. Additionally, another PAM, 了 le also appeared in the Pre-Modern period. It is used in a ' $\mathrm{V}+\}$ ' pattern in the

${ }^{45}$ Here, 他 $t \bar{a}$ is a gender-neutral pronoun. In Modern Chinese, 他 $t \bar{a}$ is the male form, while 她 $t \bar{a}$ is the female form. literature works of the Northern $\mathrm{Wei}^{46}$ (北魏 Běi Wèi 386-534 A.D.), the Southern Song (南宋 Nán Sòng 1127-1279 A.D.), and Qing periods (清 Qing 1644-1911 A.D.) (He, et.al. \& Wang, 1985).

\section{有 Yŏu as a Comparative Marker ${ }^{47}$}

Sui (2013) observes that since the Yuan dynasty (元 Yuán 1271-1368 A.D.), 有 yŏu is more grammaticalized and used in comparative construction. Wang \& Zhou (2012) consider that this function is derived from the concept of 'existence'. Examples of 有 you as a CPM are shown below.

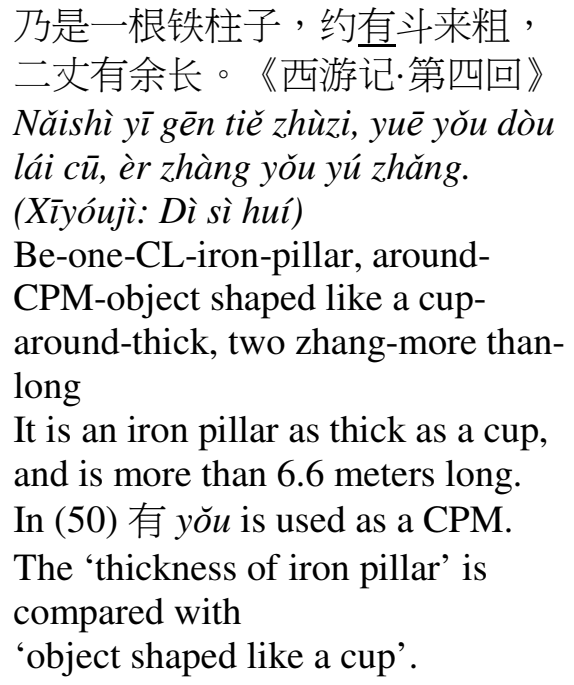

\footnotetext{
${ }^{46}$ These works are 《齐民要术》 in the Northern Wei, 《稼轩长短句》 in the Southern Song, and 《词综》in the Qing dynasties.

${ }^{47}$ Comparative marker (hereafter, 'CPM') . This term is used by $\mathrm{Xu}(2000)$ as a 'preposition'.
} 
Modern Chinese (after $19^{\text {th }}$ c.)

\section{有 Yǒu as a Verb}

In Modern Chinese, '有 +NP' patterns are similar to the Pre-Modern period, as shown in examples (51)-(54).

一个健全的家庭必须有爸爸妈 妈。(CCL Corpus)

Ȳ̄ge jiànquán de jiātíng bìxū yǒu bàba māma.

One-CL-complete-ATT-familymust-have-father-mother

A complete family must have both a father and a mother.

您房间里有窗户吗? (CCL Corpus) Nín fángjiānli yǒu chuānghu ma? Your-room-inside-have-windowPAR

Are there any windows in your room?

我有五个孩子，一男四女，再定 是老大。(CCL Corpus)

Wǒ yǒu wǔ ge háizi, ȳ̄ nán sì nǘ, Zàidìng shì lăodà.

I-have-five-CL-kid, one-boy-fourgirl, Zaiding (person name)-is-the eldest

I have five kids, one boy and four girls, Zaiding is the eldest.

我有钱时没时间去桂林，有时间 时又没钱去桂林。(CCL Corpus)

Wǒ yǒuqián shí méi shíjiān qù

Guìlín, yǒu shijiān shí yòu méi qián qù Guìlín.

When I have money, I do not have time to visit Guilin but when I have time to visit, I do not have any money.

In (51) and (52) 有 you is followed by NPs. 有 you in (51) conveys the meaning of "possesion", while (52) denotes "existence". In (53), the object of 有 you is a NP which is modified by the numeric adjective. In (54), 有 you is followed by the noun, 钱 qián "money", forming an idiomatic word.

Based on the CCL corpus, in this period, we can find quite a few idiomatic words in the '有+NP' pattern. For example, 有力 yǒulì 'strong', 有利 yǒuli 'favorable', 有效 yǒuxiào 'effective', 有益 yǒuyı̀ 'beneficial', 有害 yǒuhài 'harmful', 有 时 yǒushí 'sometimes', and 有限 yǒuxiàn 'limited'.

Similarly, pivotal pattern and indicating numerical order are still active in the Modern period, as shown in examples (55) and (56).

你不是有个哥哥在台湾吗? (CCL Corpus)

Nǐ bùshì yǒu gè gēge zài Táiwān ma?

You-not-have-CL-elder brother-in-

Taiwan-PAR

Don't you have an elder brother in Taiwan?

(56)

资格有两种, 一是道德资格, 一是 法律资格。(CCL Corpus)

Zīgé yǒu liăng zhǒng, yī shì dàodé $z \bar{\imath} g e ́, y \bar{\imath}$ shì fălì̀ zīgé

Qualification-have-two-kind, one-ismoral-qualifications, one-is-legalqualifications

There are two kinds of qualifications, one is moral qualification and the other is legal qualification. 
In (55), 哥哥 $g \bar{e} g e$ functions as the object of 有 yŏu and is the subject of the following elements, 在台湾 zài Táiwān. In (56), 有 yǒu is followed by two kinds of qualifications.

有 yǒu in '有 $+\mathrm{NUM}+\mathrm{CL}+\mathrm{ADJ}$ ' pattern which first appeared in the Pre-Modern period has been continuously used in the Modern period, as shown in example (57).

\section{这条蛇有一米长。}

Zhè tiáo shé yǒu yī mì cháng.

This-CL-snake-there is-one-meterlong

This snake is one meter long.

In (57) the general information on the length of this snake is stated. However, 有 yǒ sometimes implies quantity or degree, as shown in example (58).

$$
\begin{aligned}
& \text { 我有六十多岁了, 一切事都要准 } \\
& \text { 备。 } \\
& \text { Wǒ yǒu liùshí duō suì le, yīqiē shì } \\
& \text { dōu yào zhǔnbèi. } \\
& \text { I-there is-sixty-more-all-thing-all- } \\
& \text { want-prepare } \\
& \text { I am more than sixty years old now, } \\
& \text { so all things must be prepared. }
\end{aligned}
$$

\section{有 Yòu as a Conjunction}

According to Long (2008), 有 yòu and 零 ling went onto different paths in this period. Ever since then, 有 yòu has been commonly used in formal styles of writing, and especially used to indicate a certain period or person's age (Long, 2008), while 零 ling is inserted in numbers with zero(s), as shown in examples (59) and (60).
不久，刘即辞世，年方三十直

五。

(CCL Corpus)

Bù jiǔ, Liú jí císhì, nián fāng sānshí уо̆и wŭ.

Soon, Liu-then-pass away, age-onlythirty-CONJ-five

Soon, Liu then passed away, he was only thirty-five years of age.

$$
\begin{aligned}
& \text { 台湾地区陆军损失：两万七千二 } \\
& \text { 百人。海军损失：一万零两百 } \\
& \text { 人。(CCL Corpus) } \\
& \text { Táiwān dìqū lùjūn sǔnshī: liăngwàn } \\
& \text { qūqiān èrbăi rén. Hǎijūn sǔnshī: } \\
& \text { yīwàn líng liăngbǎi rén. }
\end{aligned}
$$

In (59) 有 yòu is used between 三十 sānshí "thirty" and 五 wú "five". Based on the CCL corpus, 有 yò is found with a number that has only two digits, while 零 ling is inserted in a number with zero. It can be seen that the use of 有 yò $u$ in Modern time is different from Medieval times. Thus, in example (45), 二万有二十七 èrwàn yòu èrshí qi "twenty thousand and twenty-seven" and 一万三千有二十四 yīwàn sān qiān yòu èrshí sì "thirteen thousand and twenty-four" must be used as 二万零二十七 èrwàn líng èrshí qi "twenty thousand and twenty-seven" and 一万三千零二十四 yìwàn sān qiān líng 
èrshí sì "thirteen thousand and twenty-four" in this period.

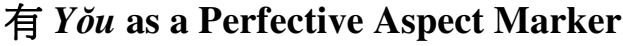

Cui (2013) claims that 有 yǒ only used in popular fiction, and magazines in Mandarin; while it is hardly ever found in the Media reports, newspapers, and academic conferences. On the other hand, 有 yǒ $u$ as a PAM is commonly used in the Southern Min dialect (Liu, 1996).

Based on the CCL corpus, only a few examples of 有 yó u as a PAM in the '有 +VP' pattern are found. In Mandarin ' $\mathrm{V}+$ 了' is the standard pattern indicating a completed action, as in (61).

\section{赵寨主你替我喝了这一杯吧。}

(CCL Corpus)

Zhào Zhàizhǔ nǐ tì wǒ hêle zhè yī bēi

ba.

Zhao Zhaizhu-you-replace-medrink-PAM-one-CL-PAR

Zhao Zhuzhu, you helped me drink this cup.

\section{有 Yŏ a a Comparative Marker}

In Modern Chinese, 有 yǒ $u$ as a CPM is more mature. Besides the '有 $+\mathrm{N}+$ 来 $+\mathrm{ADJ}$ ' pattern that derived from the Pre-Modern period, we can find new comparative constructions that are commonly used in this period. These patterns are 'A 有 $\mathrm{B}+$ 这么/那 公+ADJ+吗?', 'A 有没有 $\mathrm{B}+$ 那公+ADJ' However, it should be noted that the negative form 'A 没有 $\mathrm{B}$ (那公) +ADJ' is more common.
(62)

这个地方比较小, 只有巴掌来

大。

Zhè gè dîfāng bỉiiào xiăo, zhīyǒu bāzhăng lái dà

This-CL-place-rather-small, onlyhave-palm-around-big

This place is rather small, it is as small as our palm.

In (62) 有 yŏ is used as a CPM. The "size of this place' is compared with the 'size of palm'.

你的哥哥有我的帅吗?

Nǐ de gēge yǒu wǒ de shuài ma?

You-POSS-elder brother-CPM-I-

POSS

handsome-PAR

Is your elder brother as handsome as mine?

OR

你的哥哥有没有我的帅吗?

Nǐ de gēge yǒu wǒ de shuài ma?

You-POSS-elder brother-CPM-I-

POSS-handsome-PAR

Is your elder brother as handsome as mine?

小林有小张那公可爱吗?

Xiăo Lín yǒu Xiăo Zhāng nàme

ké’ài ma?

Xiao Lin-CPM-Xiao Zhang-PropN-

cute-PAR

Is Xiao Lin as cute as Xiao Zhang?

In (63) your elder brother is compared with mine; while in (64) Xiao Lin is compared with Xiao Zhang. 


\section{Conclusion}

From the Archaic to the Modern periods, 有 yǒ u underwent certain changes in meaning and formed its unique grammatical functions. It has been found that in the Archaic period 有 yǒu functions as a verb, meaning 'to have'. Later, 有 yŏu extended its meaning to indicate the concept of 'existence'. All functions of 有 yǒ demonstrative, conjunction, adverb, perfective aspect marker, and comparative marker/ preposition come directly from its basic meaning. This study confirms the position of Hopper and Traugott (2003) on 'the cline of grammaticality' asserting that the path of shift is from content word to function word. Table 1 below shows all the functions of 有 you and its counterparts from Archaic to Modern Chinese periods. 
MANUSYA: Journal of Humanities Regular 18.2, 2015

Table1. Functions of 有 yŏu and its counterparts from the Archaic to Modern Chinese periods

\begin{tabular}{|c|c|c|c|c|c|c|}
\hline \multicolumn{2}{|c|}{ Functions of 有 $y \check{y o u}$} & Pattern & Archaic & Medieval & Pre- & Modern \\
\hline \multirow{10}{*}{ Verb } & Possession & 有 $+\mathrm{N} / \mathrm{NP}$ & $\checkmark$ & $\checkmark$ & $\checkmark$ & $\checkmark$ \\
\hline & \multirow{9}{*}{ Existence } & 有 $+\mathrm{N} / \mathrm{NP}$ & $\checkmark$ & $\checkmark$ & $\checkmark$ & $\checkmark$ \\
\hline & & 有 $+\mathrm{NUM}+\mathrm{N}$ & $\checkmark$ & $\checkmark$ & & \\
\hline & & 有 $+\mathrm{NUM}+\mathrm{CL}+\mathrm{N} / \mathrm{NP}$ & & $\checkmark$ & $\checkmark$ & $\checkmark$ \\
\hline & & 有+NUM+CL+ADJ & & & $\checkmark$ & $(\checkmark)$ \\
\hline & & $\begin{array}{l}\text { A 有 B+这么/那么 } \\
\text { ADJ+ (吗) }\end{array}$ & & & & $\checkmark$ \\
\hline & & $\begin{array}{l}\mathrm{A} \text { 有没有 } \mathrm{B}+\text { 这么/那 } \\
\text { 么 }+\mathrm{ADJ} \text { ? }\end{array}$ & & & & $\checkmark$ \\
\hline & & $\begin{array}{l}\text { 有+N, forming } \\
\text { idiomatic word }\end{array}$ & $\checkmark$ & $\checkmark$ & $\checkmark$ & $\checkmark$ \\
\hline & & $\begin{array}{l}\text { 有 in pivotal } \\
\text { construction }\end{array}$ & $\checkmark$ & $\checkmark$ & $\checkmark$ & $\checkmark$ \\
\hline & & $\begin{array}{l}\text { 有+NP, showing } \\
\text { numerical order }\end{array}$ & & $\checkmark$ & $\checkmark$ & $\checkmark$ \\
\hline \multirow{4}{*}{\multicolumn{2}{|c|}{ Demonstrative }} & 有+ PropN & $\checkmark$ & $(\checkmark)$ & & \\
\hline & & 兹+ PropN & $\checkmark$ & $(\sqrt{ })$ & & \\
\hline & & 有+GenN & $(\sqrt{ })$ & & & \\
\hline & & 兹+GenN & $\checkmark$ & $(\sqrt{ })$ & & \\
\hline \multirow{4}{*}{\multicolumn{2}{|c|}{ Conjunction }} & $\begin{array}{l}\text { 有 between integer } \\
\text { and its remainder }\end{array}$ & $\checkmark$ & $\checkmark$ & $\checkmark$ & $\checkmark$ \\
\hline & & $\begin{array}{l}\text { Without 有 between } \\
\text { integer and its } \\
\text { remainder }\end{array}$ & $\checkmark$ & $\checkmark$ & $\checkmark$ & $\checkmark$ \\
\hline & & $\begin{array}{l}\text { Inserting 有 in the } \\
\text { number with zero }\end{array}$ & $\checkmark$ & $\checkmark$ & $\checkmark$ & \\
\hline & & $\begin{array}{l}\text { Inserting 零 in the } \\
\text { number with zero }\end{array}$ & & & $\checkmark$ & $\checkmark$ \\
\hline \multicolumn{2}{|c|}{ Adverb } & $\begin{array}{l}\text { indicating } \\
\text { characteristics and } \\
\text { intensities }\end{array}$ & $(\checkmark)$ & & & \\
\hline
\end{tabular}




\begin{tabular}{|c|c|c|c|c|c|}
\hline Functions of 有 $y \check{o} u$ & Pattern & Archaic & Medieval & $\begin{array}{c}\text { Pre- } \\
\text { Modern }\end{array}$ & Modern \\
\hline \multirow[t]{3}{*}{ Perfective aspect marker } & 既(有) $+\mathrm{V}$ & $\checkmark$ & $\checkmark$ & $\checkmark$ & $\sqrt{ }$ \\
\hline & 有 $+\mathrm{V}$ & $\sqrt{ }$ & $\checkmark$ & $\checkmark$ & $\checkmark$ \\
\hline & $\mathrm{V}+了$ & & & $\checkmark$ & $\checkmark$ \\
\hline \multirow[t]{4}{*}{ Comparative marker } & 有+N+来+ ADJ & & & $\checkmark$ & $(\checkmark)$ \\
\hline & $\mathrm{A}$ 有 B+ADJ+ (吗) & & & & $\checkmark$ \\
\hline & $\begin{array}{l}\mathrm{A} \text { 有 } \mathrm{B}+\text { 那公+ADJ+ } \\
\text { 吗 }\end{array}$ & & & & $\checkmark$ \\
\hline & $\begin{array}{l}\text { A 有没有 B+那么 } \\
\text { +ADJ' }\end{array}$ & & & & $\checkmark$ \\
\hline
\end{tabular}

Note: $\checkmark$ signifies that such a pattern appears in the particular period; while $(\checkmark)$ signifies that this pattern lost its dominance in that particular period.

\section{References}

Cai, Y. J. (1997). ‘有夏’ 等的 ‘有’ 字意义 再认识 [Rethinking on the Meaning of 'YOU' in Words like 'YOU XIA']. 河 南大学学报 (社会科学报) [Journal of Henan University (Social Science Edition)], 37, 4, 84-86.

Center for Chinese Linguistics (CCL) Corpus. Retrieved December 11, 2014 from http://ccl.pku.edu.cn:8080/ccl_corpus/ index.jsp

Chinese Text Project. (n.d.). Retrieved December 20, 2014 from http://ctext.org/ens.

Chinese Text Project. (n.d.). 史记 [The Record of the Grand Historian].
Retrieved December 20, 2014 from http://ctext.org/shiji/zhs.

Cui, N. (2013). 现代汉语普通话的 ‘有 $+V P$ '句式 ['有+VP' Pattern in Modern Mandarin]. 云南示范大学学报 (对外 汉语教学与研究版) [Journal of Yunnan Normal University (Teaching and Research on Chinese as a Foreign Language Edition)], 11, 4, 49-55.

Guo, L. J. (2012). 上古汉语中的 ‘有+名词” ['YOU+NOUN' in old Chinese']. 宜宾 学院学报 [Journal of Yibin University], 12, 3, 104-106.

Guo, Q. P. (2003). 殷噓甲骨文名片选书之 十六 [On an Explanation of the Famous Oracle Bone Number XXI of Yin 
Dynasty Ruins]. Retrieved December 10, 2014 from http://jgw.ayinfo.ha.cn

Guo, X. L. (2005). 汉语史论集 [Works on the history of Chinese]. Beijing:

The Commericial Press.

Gushiwen Wang. (n.d.). 资治通鉴

[Comprehensive Mirror for the Ruler].

Retrieved

December 19, 2014 from

http://www.gushiwen.org/GuShi

Wen_287922eed1.aspx

He, L. S., Ao, J. H., Wang, K. Z., Mai, M.

Q., Wang, H. F. (1985). 古代汉语虚词 通释 [An Explanation on Function Words in Ancient Chinese]. Beijing: Beijing University Press.

Hopper, P. J., Elizabeth, T. (2003). Grammaticalization. Cambridge: Cambridge University Press.

Hornby, A. (1994). Oxford Advanced Learner's Dictionary of Current English. London: Oxford University Press.

Huang, Q. Y. (1981). 古国、族名前的 “有” 字新解 [A New Explanation on the Word 'YOU' before the Ancient Kingdom and Tribe's name]. 中国语文 [Chinese], 1.

Huang, Y. T. (1985). 关于古代国、族名前 “有” 字的训释 [An Explanation on the Word 'YOU' before the Ancient Kingdom and Tribe's name]. 贵州民族 学院学报(哲学社 会科学版) [Journal of Guizhou University for Ethnic
Minorities (Philosophy and Social Sciences)], 82-83.

Jin, X. P. (2012). Analysis of Some Chinese Concepts derived from Greek. Retrieved December 10, 2014 from http://site.douban.com/134820/widget/ notes/5911418/note/236784007/

Legge, J. (1893). Confucius Analects, the Great Learning \& The Doctrine of the Mean. Dover Publication. New York: USA.

(1898). The She King or the Book of Poetry. Vol 4. of The Chinese Classics.

Li, C. N., Thompson, S. A. (1981). Mandarin Chinese: A Functional Grammar. Berkeley and Los Angeles University of California Press.

(1989). Mandarin Chinese: A

Functional Reference Grammar.

Berkeley and Los Angeles University of California Press.

Li, Y. M. (1982). 所谓名词词头 “有” 新议 [The New Proposal on So-called Noun Prefix 'YOU']. 中州学刊 [Academic Journal Of Zhongzhou], 3, 105-106.

Liu, L. (1996). 古汉语 “有+VP’ 结构中 '有' 的表体功能 [ Aspectual Function of 'YOU' in 'YOU+VP' Structure in Old Chinese]. 江苏师范大学学报（哲学社 会科学版）[Journal of Jiangsu Normal University (Philosophy and Sciences Edition) ], 1, 66-68. 
Long, H. P. (2008). 表数连接词 ‘有” 分析 [The Analysis of Numeral Linking word 'YOU']. 嘉应学院学报（哲学社会科 学) [Journal of Jiaying University (Philosophy \& Social Science)], 26, 2, 112-116.

Measurement Law. (1929). Retrieved December 19, 2014 from http://zh.wikipedia.org /wiki/\%E5\%B8\%82\%E5\%88\%B6

Ni, H. Q. (2004). 从《国语》看 ‘有’ 字的 早期用法. [A Study of the Earliest Usage of 'YOU' based on Guоyu]. 广州 大学学报 (社会科学版) [Journal of Guangzhou University (Social Science Edition)], 3, 6, 48-52.

Qin, J. M., Zhang, M. R. (1985). 也谈古国 名前的 “有” 字 [A Discussion on 'YOU' before the Ancient Kingdom's Name]. 中 国语文 [Chinese], 4, 286.

Song, S. Q. (1996). 《论语》中的 ‘有” 字与 '无' 字 ['YOU' and 'WU' in the Confucius Analects]. 语文研究 [Linguistic Research], 1, 44-47.

Sui, Y. L. (2013). 有语法化过程. [The Process of Grammaticalization about the Chinese Word 'YOU'. 韶关学院学报 (社会科学) [Journal of Shaoguan University (Social Science), 34, 3, 78-82.

Teng, S. H. (1973). Journal of Chinese linguistics: Negatives and Aspect in Chinese. 1, 14- 37.
The Corpus of Pure Land. (n.d). 上座部与

大乘佛教 [Theravada - Mahayana

Buddhism] Retrieved December 19, 2014 from

http://wap.goodweb.cn/index.asp

The Royal Institute [ราชบัณฑิตยสถาน]. (2010).

Dictionary of Linguistics (applied linguistics). Bangkok: Rungsin Press.

Theobald, U. (2010). 大戴礼记 [Records of Ritual Matters by Dai Senior]. Retrieved December 11, 2014, from http://www.chinaknowledge.de/ Literature/Classics/dadailiji.html (2010). 国语 [Discourses of the States]. Retrieved December 11, 2014, from http://www.chinaknowledge.de/ Literature/ Science/shuo wenjiezi.html (2010). 后汉书 [Book of the

Later Han Dynasty]. Retrieved December 11, 2014, from http://www.chinaknowledge.de/ Literature/Historiography/houhanshu.html (2010). 论语 [The Confucian Analects]. Retrieved December 11, 2014, from http://www.chinaknowledge.de/ Literature/ Science/shuowenjiezi.html (2010). 佮书 [Book of

Documents]. Retrieved December 11, 2014, from http://www.chinaknowledge.de/ Literature/Classics/shangshu.html 


$$
\text { . (2010). 诗经 [Book of }
$$

Songs]. Retrieved December 11, 2014, from http://www.chinaknowledge.de/ Literature/Classics/shijing.html . (2010). 说文解字

[Explaining Simple and Analyzing Compound Characters]. Retrieved December 11, 2014, from http://www.chinaknowledge.de/ Literature/ Science/shuo wenjiezi.html . (2010). 宋书 [The book of the (Liu-)Song]. Retrieved December 11, 2014, from http://www.chinaknowledge.org/ Literature/ Historiography/songshu.html . (2010). 魏书 [The Book of the Wei Dynasty]. Retrieved December 11, 2014, from http://www.chinaknowledge.de/ Literature/Historiography/weishu.html . (2010). 左传 [Commentary of Zuo]. Retrieved December 11, 2014, from http://www.chinaknowledge.de/ Literature/Classics/ chunqiuzuozhuan.html

Wang, T. J. (2004). 试说动词 '有” [The Usage of the Chinese Character 'YOU' as a Verb].南京工程学院学报（社会科 学报) [Journal of Nanjing Institute of Technology (Social Science Edition)], 4, 2, 11-13.

Wang, Y. Z. (1798) 经传释词 [The Book of Expletives]. Jiangsu: Jiangsu Gaoyou Press.
Wang, Y., Zhou, Y. F. (2012). “有”字句的 历时考察和横向比较 [A Historical Review and Horizontal Comparison on YOU Sentence]. 华中师范大学学报 (人文社会科学版) [Journal of Huazhong Normal University (Humanities and Social Sciences)], 51, 5, 91-99.

Wen, L. (1993). Chinese Language Review: Guanyu YOU de Sikao, 12, 42.

Xia, Z. N. (1989). 辞海 [Sea of Words]. Shanghai: Shanghai Cishu Press.

Xu, Z. M. (2000). 论介词 '有' [On 'YOU' as a Preposition]. 殷都学刊 [Yindu Journal], 102-105.

Yang, B. J. (1981). 古汉语虚词 [Ancient Chinese Function Words]. Beijing: Zhonghua Press.

Yang, B. J. \& He, L. S. (1992). 古汉语语法 及其发展 [Classical Chinese Grammar and its Development]. Beijing: Yuwen Press.

Yang, W. Q., Dong, Y.W. (2005). 语言变异: 汉语 ‘有+VP' 句简析 [Language Variation: A Brief Discussion on 'YOU+VP' Sentence]. Retrieved December 19, 2014 from http:// ddxs.cbpt.cnki.net/WKD/ WebPublication/paperDigest. aspx ? paperID $=3753 \mathrm{ed} 72$ 70c2-4ee7-9c31-4888783933f3 
Yue, X. H. (n.d.). 佛教的梗概（续) [A

General Outline of Buddhism

(Continued)]. Retrieved December 19, 2014 from

http://www.drbachinese.org/vbs/publish/

341/vbs341p032.htm

Zhang W.G (1996). 论先秦汉语的“有

(无) +VP 结构' [A Discussion on

'YOU(WU)+VP

Construction' in Pre-Qin Dynasty]. 广西

大学学报 [Journal of Guangxi

University], 3. 